\title{
Spatiotemporal ecology of two Neotropical herbivorous mammals
}

\author{
Douglas de Matos Dias ${ }^{1}$; Meyline de Oliveira Souza Almeida ${ }^{2,3}$; Talita Guimarães de Araújo-Piovezann ${ }^{2,4}$ \& José Oliveira Dantas ${ }^{2,5}$ \\ 1 Universidade Federal de Minas Gerais (UFMG), Instituto de Ciências Biológicas (ICB), Departamento de Biologia Geral (DBG), \\ Programa de Pós-Graduação em Ecologia, Conservação e Manejo da Vida Silvestre. Belo Horizonte, MG, Brasil. \\ ORCID: http://orcid.org/0000-0001-9664-860X.E-mail: diasdm.bio@gmail.com (corresponding author). \\ ${ }^{2}$ Instituto Federal de Educação, Ciência e Tecnologia de Sergipe (IFS). São Cristóvão, SE, Brasil. \\ ${ }^{3}$ ORCID: http://orcid.org/0000-0002-6612-1855. E-mail: meeyzinha.souza@hotmail.com \\ ${ }^{4}$ ORCID: http://orcid.org/0000-0001-9943-4332. E-mail: talit_a@hotmail.com \\ ${ }^{5}$ ORCID: http://orcid.org/0000-0002-2023-5531.E-mail: josedantas336@gmail.com
}

\begin{abstract}
On this study, we used camera traps in a Semi deciduous Seasonal Forest, northeast of Brazil, to estimate the frequencies of occurrence of two Neotropical herbivorous mammals: the spotted paca (Cuniculus paca) and the tapeti (Sylvilagus brasiliensis), analyzing their seasonal variations of spatial distribution. We also characterized the activity pattern of the species and their seasonal variation. The herbivorous frequencies of occurrence were constant during all the seasons. In general, both species were mostly active at night. However, between the rainy and dry season, we identified differences in spotted paca activity peaks. Here we present one of the first studies on the tapeti, whose ecology is understudied. Our results also show a general view of the spotted paca and tapeti behavior strategies to seasonal variations. Due to the scarce food resource in the dry season, possibly these herbivorous need to search for different kinds of food available IFS around.
\end{abstract}

Key-Words. Cuniculus paca; Sylvilagus brasiliensis; Agroforestry mosaic; Distribution patterns; Activity patterns.

\section{INTRODUCTION}

At seasonal climatic environments, the main resources availability reduces because of increasing dry season (Thrash et al., 1995). Thus, when resources become scarce, animals are forced to aggregate near them (Valeix et al., 2007). Consequently, species tend to exhibit behavioral adjustments to deal with these adverse conditions (Thrash et al., 1995; Ferreguetti et al., 2017). Behavior is a variable phenotype resulting from interaction between environmental changes and the animal's internal state (Morgan, 2004). In this sense, the combination of seasonal variations in the environmental conditions such as temperature and availability of food can also cause changes in species activity patterns (Pita et al., 2011). Daily activity patterns of many tropical animals are known in general terms (i.e., whether a species is mostly nocturnal or diurnal) (e.g., Emmons $\&$ Feer, 1997) but details of these patterns are less well described.

The spotted paca Cuniculus paca (Linnaeus, 1766) and tapeti Sylvilagus brasiliensis (Linnaeus, 1758) are Neotropical herbivorous mammals and sympatric in most of their distributions (AMCELA et al., 2008; Emmons, 2016). The spotted paca lives in different forest types, such as mangroves, semi deciduous forests and savannas (Oliveira \& Bonvicino, 2011). It occurs mainly at gallery forests close to rivers and other bodies of water, where it builds its own burrow or rests in shelters of other species (Emmons, 2016; Figueroa-de-León et al., 2017). The spotted paca is a territorial and solitary animal and it is eventually seen in pairs (Pérez, 1992). Its activity pattern is predominately nocturnal (Michalski \& Norris, 2011; Dias et al., 2018) and its diet could vary according to seasonality. It is an opportunistic herbivorous with preference to fruits (Pérez, 1992; Dubost \& Henry, 2006).

The tapeti is a generalist mammal occupying from deciduous and secondary forests to open areas (Chapman \& Flux, 1990). It commonly lives at transition environments among forests, open fields and the edge of watercourses (AMCELA et al., 2008; Reis et al., 2011). It has crepuscular and nocturnal habit and its diet is based on fruits, leaves, roots and seeds. (Reis et al., 2011). Although it has been commonly recorded at wildlife inventories and most of tropical forest sites are included into its occurrence area, its ecology has unfortunately been neglected (Silva Júnior et al., 2005; Dantas et al., 2016; Andrade \& Hernández, 2017). 
Thus, it is fundamental to understand the behavioral adjustments of these herbivores to environmental changes. Our objectives were: 1) Evaluate the seasonal variation of the frequency of occurrence and distribution of spotted paca and tapeti, in a semi deciduous forest; 2) Characterize their activity patterns, and investigate possible changes in temporal activity between rainy and dry seasons.

\section{MATERIAL AND METHODS}

\section{Study area}

We conducted this study at a semi deciduous Atlantic forest patch of $\sim 400$ ha with different stages of succession, including patch of the oil palm Elaeis guineensis Jacq. and secondary vegetation (capoeira). The area belongs to Federal Institute of Education, Science and Technology of Sergipe (IFS), São Cristóvão (Fig. 1). The region presents hot and humid weather with the rainy season from March to August (autumn and winter) (INPE, 2018). The average annual rainfall is of $1,500 \mathrm{~mm}$, and $73 \%$ of this volume falls during the wet season, following historical data from the Secretaria de Estado do Meio Ambiente e dos Recursos Hídricos of Sergipe. The fragment is located within the metropolitan region of Aracaju, the Sergipe state capital, and it is surrounded by a matrix of mixed farmland.

\section{Sampling}

We sampled a total of 33 camera sites (i.e., our sampling units), randomly selected within of the forest patch. The mean distance between two simultaneously active cameras was $665 \mathrm{~m}$. One camera was placed at each site for 32 consecutive days in mean and operated for $24 \mathrm{~h}$. Due to the limited number of cameras, we rotated cameras among sites within patch. Specifically, we deployed cameras at 2 sites for 32 consecutive days (on average), then we moving cameras to another 2 sites within the patch. We repeated this process until all 33 sites were sampled. Unfortunately, on two occasions had stolen equipment problems, which compromised our sampling effort. We carried out this study during 21 months from July 2015 to August 2017. We did not use baits to attract animals. We defined as frequency of occurrence (FO) of spotted paca and tapeti the number of independent records for each species divided by the total sampling effort (in days), during the entire study.

\section{Data analysis}

Although the studied species have average home ranges lower than 4 ha (Swihart, 1986; Benavides et al., 2017), we tested whether the species FO would be correlated with the distances between the camera sites. As
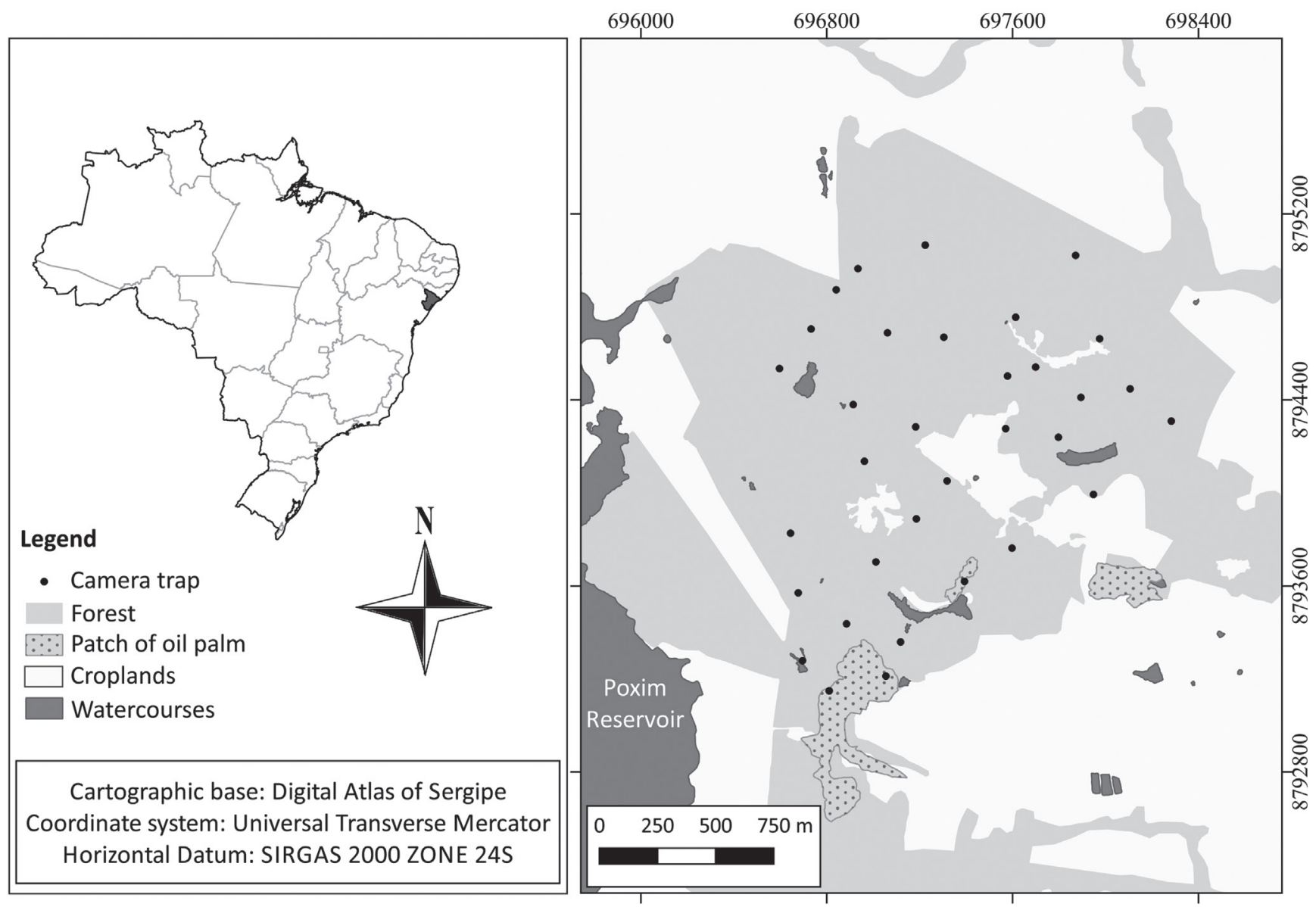

Figure 1. Forest Fragment location at the Federal Institute of Sergipe (IFS), São Cristóvão, SE. The insertion at the top-right hand corner represents the Brazilian territory with a highlight to Sergipe state (on dark gray). 
the distance from camera sites not was highly correlated with the frequency of occurrence that from both spotted paca and tapeti $(r=-0.09 ; p=0.58$ and $r=0.22 ; p=0.21$ respectively), we treated the camera trap sites as sampling units, assuming that the catch rates were independent due to their spacing.

We also assumed that all the capture events of the species $\geq 1$ h of interval were independent (Goulart et al., 2009; Dias et al., 2018). To verify the variation of the species occurrence between the wet and dry season, we plotted maps to illustrate the individual distributions of spotted paca and tapeti. Additionally, we verified possible seasonal differences in the FO of each species through the nonparametric Mann-Whitney test (U).

To describe the activity pattern of the species, we turned the activity records of each species into solar time, with the objective of adjusting the real time to the circadian cycle of the species (Linkie \& Ridout, 2011). We used the sunrise and sunset time of the study site to define the time adjustment and its transformations, through the Tropsolar 5.0 Software (Cabús, 2015). We categorized the activity of each target species as being predominantly nocturnal when most of the activity occurred between $1 \mathrm{~h}$ after the sunset and $1 \mathrm{~h}$ before the sunrise. For strictly nocturnal species, we considered the ones whose activity periods were exclusively recorded during the night (Dias et al., 2018, 2019a). We defined the cathemeral period occurring between $1 \mathrm{~h}$ before and after sunrise and sunset (see Massara et al., 2018).

Through the time records, we determined the general activity pattern of spotted paca and tapeti in the IFS. We determined the diurnal cycle distribution of the camera traps records of each species using circular statistics, which tests if the set of angles (the records for each hour of the day) is evenly distributed (Zar, 2010). We verified the uniformity of the circular distribution of the collected records during the study period using Rayleigh Test $(Z)$ through the Oriana software 4.01 (Kovach Computing Services, Anglesey, UK). Using the Overlap package (Meredith \& Ridout, 2014), we estimated the density of the activity of each species using the kernel density, a nonparametric approach that evaluates the probability function of the density of a random variable (Worton, 1989) through $R$ software (R Development Core Team, 2017). To complement this analysis, we compared the 24-hour cycles of the species between rainy and dry seasons using the Mardia-Watson-Wheeler test (W), run in Oriana 4.01 (Kovach Computing Services, Anglesey, UK).

\section{RESULTS}

We had 106 records of spotted paca and 69 of tapeti (totaling 175 independent records). The spotted paca frequency of occurrence between the rainy season $(\mathrm{FO}=0.07)$ and the dry season $(\mathrm{FO}=0.12)$, was not significantly different $(U=190.5 ; p=0.25)$. However, its distribution was limited only at a few sites during the dry season (Fig. 2). We also did not find differences on the tapeti frequency of occurrence $(U=183$; $p=0.43)$ be-
Table 1. Rayleigh's uniformity test ( $Z$ ) for the temporal activity; value of $Z$ tabulated for significance level of $0.05\left(Z_{\text {critical }}\right)$, based on the number of independent records $(\mathrm{N})$ collected for each species. The classification of the activity was based on the proportion of observations in each period of the circadian cycle.

\begin{tabular}{lcccccc}
\hline \multicolumn{1}{c}{ Species } & $\boldsymbol{Z}$ & $\boldsymbol{p}$ & $\boldsymbol{Z}_{\text {critical }}$ & $\mathbf{N}$ & Distribution & Activity \\
\hline Rainy season & & & & & & \\
$\quad \begin{array}{l}\text { Spotted paca } \\
\text { Tapeti }\end{array}$ & 24.4 & $5.6 \times 10^{-11}$ & 2.97 & 41 & Non-uniform & Strictly nocturnal \\
\hline Dry season & 15.3 & $2.3 \times 10^{-7}$ & 2.98 & 50 & Non-uniform & Predominantly nocturnal \\
$\quad \begin{array}{l}\text { Spotted paca } \\
\text { Tapeti }\end{array}$ & 29.8 & $1 \times 10^{-12}$ & 2.98 & 65 & Non-uniform & Predominantly nocturnal \\
\hline
\end{tabular}

tween the rainy season $(F O=0.09)$ and the dry season (FO $=0.03$ ). Its distribution followed the same pattern previously observed for spotted paca in this work (Fig. 2).

The Rayleigh Test $(Z)$ showed that the daily activity of the two species did not followed a uniform distribution (Table 1). In general, the small herbivorous presented activity predominately nocturnal (observations $>60 \%$ ). During the rainy season, only the spotted paca presented an activity pattern strictly nocturnal $(100 \%$ of the records). Despite the predominantly nocturnal pattern (88\%), tapeti presented a considerable crepuscular activity with $22 \%$ of the records in this period. During the dry season, the spotted paca was mostly active at night (92\% of records), but with some records at crepuscular periods (8\%). The tapeti activity followed similar pattern to the rainy season, with $79 \%$ of their records during the nocturnal period.

The W Test showed significant differences among the circadian distributions of the spotted paca between rainy and dry season $(\mathrm{W}=7.74 ; \mathrm{p}=0.02 ;$ Fig. $3 \mathrm{~A})$, but there were no differences on the distribution of the daily records of the tapeti between seasons $(W=2.67 ; p=0.26$; Fig. 3B).

\section{DISCUSSION}

The frequency of occurrence of the small herbivorous did not vary with the climatic seasonality at the study site, suggesting that the spotted paca and tapeti abundances were constant during the year. Although, our sample design did not allow us to estimate the real abundance of species, studies indicate that there is a correlation between the photographic rate measured in terms of traps/day and the abundance of the animals (Carbone et al., 2002). In fact, both as spotted paca and tapeti could reproduce from two to three times a year (Chapman \& Flux, 1990; Pérez, 1992). These breeding taxes could explain our results for the constant frequencies of occurrence found during this study.

We identified a seasonal variation on the species distribution at IFS. During the rainy season, numerous small lagoons were found as well as a great diversity of fruits, such as Byrsonima sp. L., Eugenia candolleana DC., Genipa americana L. and Licania tomentosa Benth, Talisia esculenta (A. St.-Hil.) Radlk. This could benefit the wide 
use of the area by the mammals. On the other hand, during the dry season, only the greatest lagoons had water and just few arboreal species could bear fruits, such as Mangifera indica L. and the oil palm Elaeis guineensis Jacq. Considering the water availability as a relevant factor on the structure of mammal communities, due to its influence on the species distributions (Ferreguetti et al., 2017; Dias et al., 2019b), a variation on its availability could influence the distribution of the small herbivorous at IFS, mainly the spotted paca. Thus, the spotted paca selectively used the forest fragment at IFS, during the dry season, probably due to the reduction of the superficial water sources. The proximity to permanent watercourses has been described as a key-variable for the selective use of burrows by spotted paca (Figueroa-de-León et al., 2017). In the same way, hydric bodies have been the main habitats elements related to the reproduction of this rodent. (Figueroa-de-León et al., 2017). Therefore, the low lagoons availability during the dry season reflects on the reduction of its distribution at IFS.

Alternatively, the low fruits availability during the dry season can also explain the reduction on the spotted paca and tapeti distributions. Some studies showed that food availability drives the spatial behavior in small mammals (Schradin \& Pillay, 2006; Cooper \& Randall, 2007; Quirici et al., 2010). Spotted paca and tapeti feed largely on fruits; however, these species are opportunistic and could adjust their diet according to seasonal
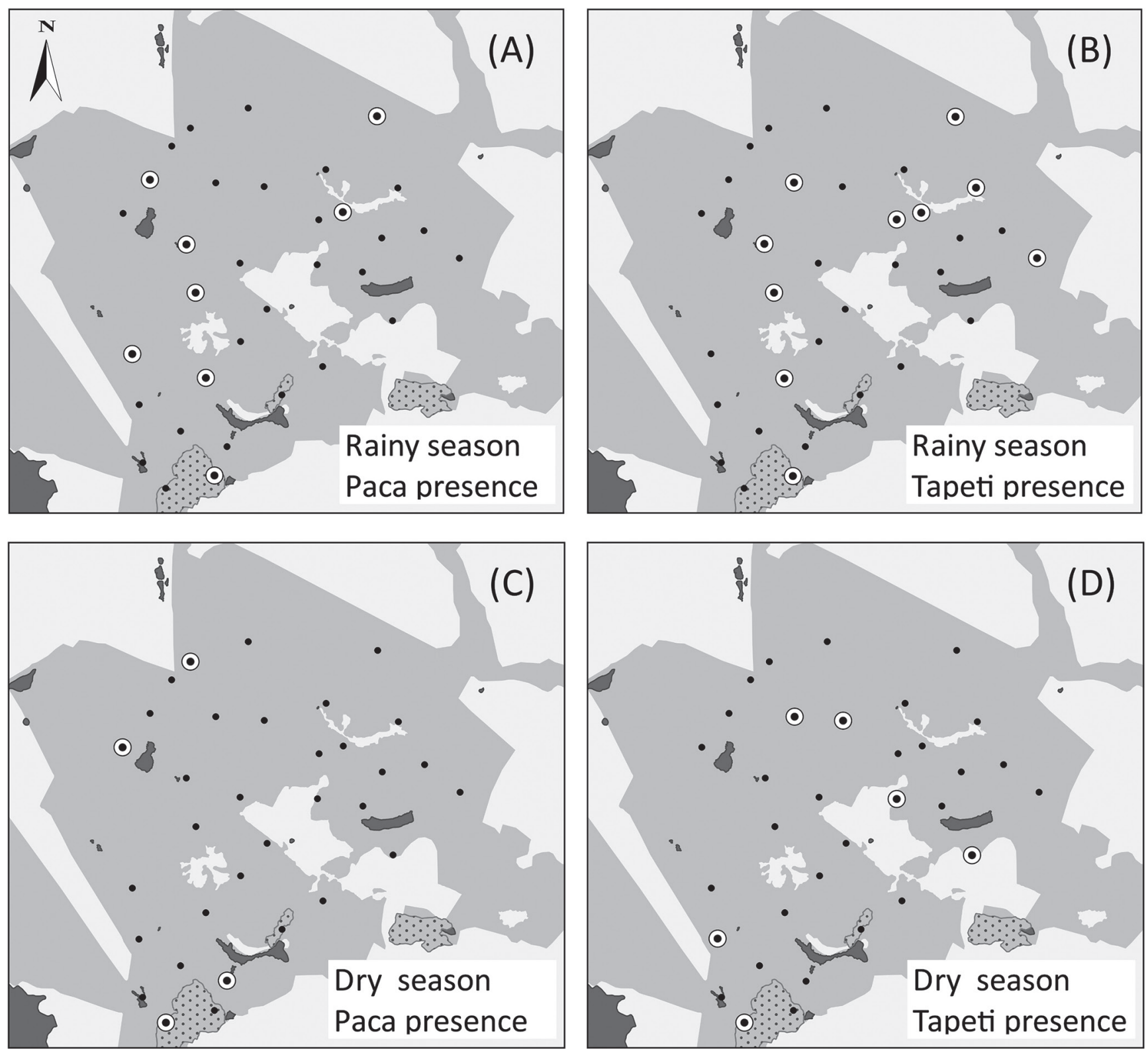

$0 \quad 250 \quad 500 \quad 750 \mathrm{~m}$

$\odot$ Sites with herbivores species present

\section{- Sites with herbivores species absent}

Figure 2. Individual distributions of spotted paca and tapeti at a forest fragment at IFS, São Cristóvão, SE, Brazil. We collected the data through camera traps records at 33 sample sites from July 2015 to August 2017. The presence of each species was inferred from species camera trap records from each sample site, while the absence of the species was inferred by the lack of these records. 
variations of the food availability (Dubost \& Henry, 2006; Reis et al., 2011). Nonetheless, during the dry season, the spotted paca was mostly active at sites close to oil palm patches Elaeis guineensis Jacq and to the forest fragment edge. Although it was described as typical of the forest (Pérez, 1992; Oliveira \& Bonvicino, 2011), in agroforestry systems in the Bolivian Amazon, Benavides et al. (2017) showed that the species tended to be more abundant at agricultural crops than in secondary forests. This corroborates with the distribution of this rodent at IFS during the dry season, once the surrounding matrix is mostly composed by sugar cane and corn fields and orchards of species of fruit trees, such as Anacardium occidentale L., Passiflora edulis Sims, Annona squamosa L., Malpighia emarginata DC. and Annona muricata L., that bear fruits at different periods of the year and they could represent an important food resource for spotted paca in this season. The tapeti is more flexible than spotted paca in the habitat use. It lives typically at open areas, forest edges and it could live at perturbed areas (Silva Júnior et al., 2005; Reis et al., 2011). Therefore, during the rainy season, when the native fruits are available, the tapeti occurs more in the forest interior but during the dry season, it tends to be more frequent at the forest edge sites, probably due to its search for alternative food resources.

The activity pattern for spotted paca and tapeti found here corroborates with previous studies that indicated a predominately-nocturnal activity for these species (Blake et al., 2012; Dias et al., 2018). During the rainy season, the

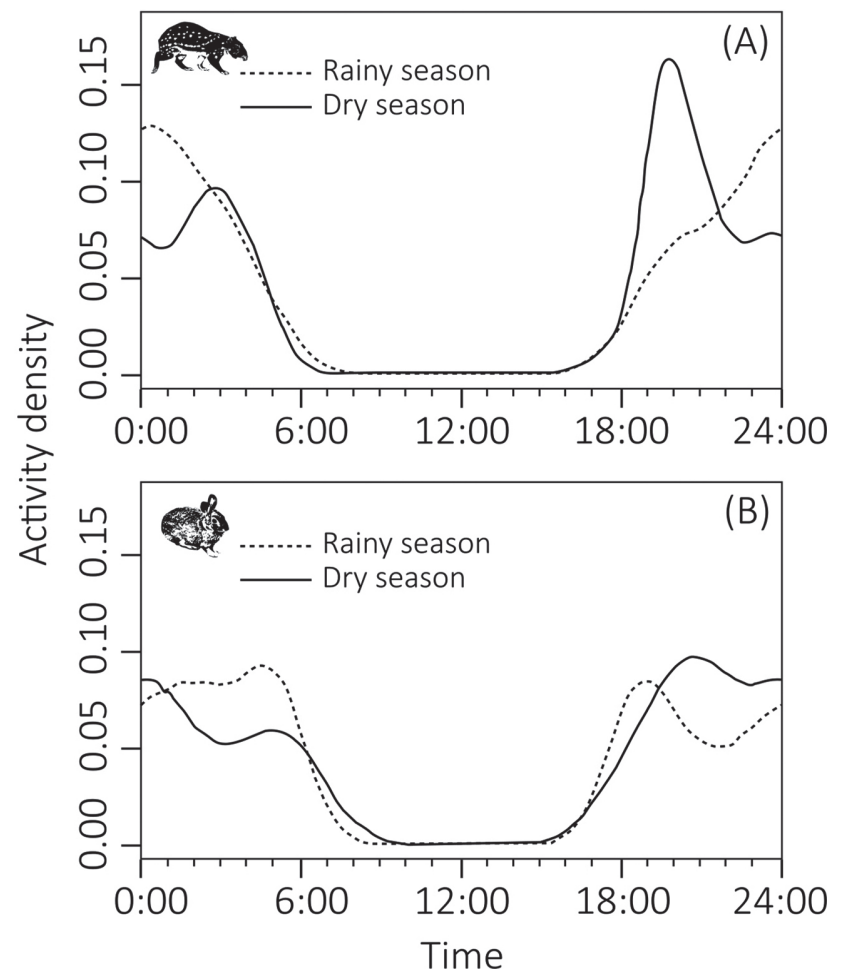

Figure 3. Activity density pattern of the spotted paca (A) and tapeti (B) during the rainy and dry seasons, at a forest fragment, IFS, São Cristóvão, SE, Brazil. The $X$-axis shows the time of the day. During the rainy season, the average sunrise time was at 06:15 and average sunset time at 17:45. For the dry season, the average sunrise time was at 05:45 and the average sunset time was at 18:15. spotted paca was strictly nocturnal, while tapeti was predominately nocturnal. On this season, the spotted paca presenting a peak of activity at 00:00 $\mathrm{h}$ and the tapeti showed a constant activity during the nocturnal period. During the dry season, the spotted paca shifted its activity pattern, exhibiting a bimodal pattern with peak periods of activity at 03:00 $\mathrm{h}$ and 20:00 $\mathrm{h}$. This seasonal variation on the spotted paca activity could be due to the low food availability during the dry season, making the species to increase its activity period during the night for searching food.

Here we present one of the first studies on the tape$\mathrm{ti}$, whose ecology is understudied. Our results also show a general view of the spotted paca and tapeti behavior strategies to seasonal variations. Due to the scarce food resource in the dry season, possibly these herbivorous need to search for different kinds of food available IFS around.

Given that the spotted paca and tapeti could be considered as a target group for the conservation efforts due to its influence on the community diversity and structure, just as on the plants recovering trough the seed dispersion and predation (Wright et al., 2000). Future studies should be done at areas with different degree of disturbances in order to evaluate the influence of habitat perturbation on these species behavior. In addition, trophic data can provide additional information on the ecology of these mammals.

\section{ACKNOWLEDGMENTS}

We thank to the Programa de Iniciação Cientifica (PIBIC/CNPq) and to Instituto Federal de Sergipe for the logistic support. Thank you also to the anonymous reviewer wo kindly reviewed and helped to improve the manuscript.

\section{REFERENCES}

Andrade, R.P. \& Hernández-Ruz, E.J. 2017. Sylvilagus brasiliensis (Linnaeus 1758) (Mammalia, Lagomorpha, Leporidae): first record for Uruará, south western Pará state, Amazonia. International Journal of Research Studies in Biosciences, 5: 1-3.

Benavides, C.; Arce A. \& Pacheco, L.F. 2017. Home range and habitat use by pacas in a montane tropical forest in Bolivia. Acta Amazonica, 47: 227-236.

Blake, J.G.; Mosquera, D.; Loiselle, B.A.; Swing, K.; Guerra, J. \& Romo, D. 2012. Temporal activity patterns of terrestrial mammals in lowland rainforest of eastern Ecuador. Ecotropica, 18: 137-146.

Cabús, R. 2015. Tropsolar 5.0. Grupo de Pesquisa em Iluminação (GRILU). Maceió Brasil. http://www.ctec.ufal.br/grupopesquisa/gril. Access in: 04/06/2017.

Carbone, S.; Cristie, S.; Conforti, K.; Coulson, T.; Franklin, N.; Ginsberg, J.R.; Griffiths, M.; Holden, J.; Kinnaird, M.; Laidlaw, R.; Lynam, A.; Macdonald, D.W.; Martyr, D.; Mcdougal, C.; Nath, L.; O'brien, T.; Seidensticker, J.; Smith, D.J.L.; Tilson, R. \& Wan Shahruddinw, N. 2002. The use of photographic rates to estimate densities of cryptic mammals. Animal Conservation, 5: 121-123. 
Chapman, J.A. \& Flux, J.E.C. 1990. Rabbits, Hares and Pikas. Status survey and Conservation Action Plan. Gland, IUCN.

Cooper, L.D. \& Randall, J.A. 2007. Seasonal changes in home ranges of the giant kangaroo rat (Dipodomys ingens): a study of flexible social structure. Journal of Mammalogy, 88: 1000-1008.

Dantas, A.R.C.; Menezes, F.H.; Serra, K.S.; Barbosa, E.D.0. \& FernandesFerreira, H. 2016. First record of Sylvilagus brasiliensis (Linnaeus, 1758) (Lagomorpha, Leporidae) in Rio Grande do Norte state, Northeast Brazil. Check List, 12: 1-4.

Dias, D.M.; Campos, C.B. \& Rodrigues, F.H.G. 2018. Behavioural ecology in a predator-prey system. Mammalian Biology, 92: 30-36.

Dias, D.M.; Massara, R.L.; Campos, C.B. \& Rodrigues, F.H.G. 2019a. Feline predator-prey relationships in a semi-arid biome in Brazil. Journal of Zoology, version online: 1-10.

Dias, D.M.; Massara, R.L.; Campos, C.B. \& Rodrigues, F.H.G. 2019b. Human activities influence the occupancy probability of mammalian carnivores in the Brazilian Caatinga. Biotropica, 51:253-265.

Dubost, G. \& Henry, 0. 2006. Comparison of diets of the acouchy, agouti and paca, the three largest terrestrial rodents of French Guianan forests. Journal of Tropical Ecology, 22: 641-651.

Emmons, L. 2016. Cuniculus paca. In: The IUCN Red List of Threatened Species 2016: e.T699A22197347. http://dx.doi.org/10.2305/IUCN.UK.2016-2. RLTS.T699A22197347.en. Download in: 21/07/2018.

Emmons, L.H. \& Feer, F. 1997. Neotropical rainforest mammals. A field guide. 2. ed. Chicago, University of Chicago Press.

Ferreguetti, A.C.; Tomas, W.M. \& Bergallo, H.G. 2017. Differences in the mammalian habitat use in a mosaic of vegetation types of an Atlantic Rain-Forest reserve, Brazil. Mastozoología Neotropical, 24: 355-364.

Figueroa-de-León, A.; Naranjo, E.J.; Parales, H.; Santos-Moreno, A. \& Lorenzo, C. 2017. Abundance, density and habitat use of lowland paca (Cuniculus paca, Rodentia - (uniculidae) in the Lecandon Rainforest, Chiaspas, Mexico. Therya, 8: 199-208.

Goulart, F.V.B.; Cáceres, N.C.; Graipel, M.E.; Tortato, M.A.; Ghizoni Jr., I.R. \& Oliveira-Santos, L.G.R. 2009. Seleção de habitat por mamíferos de grande porte em uma mata atlântica do sul do Brasil. Mammalian Biology, 47: 182-190.

Instituto Nacional de Pesquisas Espaciais (INPE). 2018. Centro de previsão do tempo e estudos climáticos. Available at: http://clima1.cptec.inpe.br/ estacoes.

Linkie, M. \& Ridout, M.S. 2011. Assessing tiger-prey interactions in Sumatran rainforests. Journal of Zoology, 284: 224-229.

Massara, R.L.; Paschoal, A.Md.O.; Bailey, L.L.; Doherty Jr., P.F.; Hirsch, A. \& Chiarello, A.G. 2018. Factors influencing ocelot occupancy in Brazilian Atlantic Forest reserves. Biotropica, 50: 125-134.

Meredith, M.\& Ridout, M. 2014. Overlap: Estimates of Coefficient of Overlapping for Animal Activity Patterns. R Package Version 0.2.4. Access in: 06/2018.

Mexican Association for Conservation and Study of Lagomorphs (AMCELA); Romero Malpica, F.J. \& Rangel Cordero, H. 2008. Sylvilagus brasiliensis.
In: The IUCN Red List of Threatened Species 2008: e.T41298A10418161. http://dx.doi.org/10.2305/IUCN.UK.2008.RLTS.T41298A10418161.en. Download in: 21/07/2018.

Michalski, F. \& Norris, D. 2011. Activity pattern of Cuniculus paca (Rodentia, (uniculidae) in relation to lunar illumination and other abiotic variables in the southern Brazilian Amazon. Zoologia, Curitiba, 28: 701-708.

Morgan, E. 2004. Ecological significance of biological clocks. Biological Rhythm Research, 35: 3-12.

Oliveira, L.O. \& Bonvicino, C.R. 2011. Ordem Rodentia. In: Reis, N.R.; Peracchi, A.L.; Pedro, W.A. \& Lima, I.P. (Eds.). Mamíferos do Brasil. Londrina, Edição do Autor. p. 358-414.

Pérez, M.E. 1992. Agouti paca. Mammalian Species, 404: 1-7.

Pita, R.; Mira, A. \& Beja, P. 2011. Circadian activity rhythms in relation to season, sex and interspecific interactions in two Mediterranean voles. Animal Behaviour, 81: 1023-1030.

Quirici, V.; Castro, R.; Ortiz-Tolhuysen, L.; Chesh, A.; Burger, J.; Miranda, E.; Cortés, S.; Hayes, L. \& Ebensperger, L. 2010. Seasonal variation in the range areas of the diurnal rodent 0 ctodon degus. Journal of Mammalogy, 91: 458-466.

R Development Core Team. 2017. R: A Language and Environment for Statistical Computing. Vienna, R Foundation for Statistical Computing. https:// www.R-project.org.

Reis, N.R.; Filho, H.0. \& Silveira, G. 2011. Ordem Lagomorpha. In: Reis, N.R.; Peracchi, A.L.; Pedro, W.A. \& Lima, I.P. (Eds.). Mamíferos do Brasil. Londrina, Edição do Auto.: p. 151-154.

Schradin, C. \& Pillay, N. 2006. Female striped mice (Rhabdomys pumilio) change their home ranges in response to seasonal variation in food availability. Behavioral Ecology and Sociobiology, 17: 452-458.

Silva Júnior, J.S.; Oliveira, J.A.; Dias, P.A. \& Oliveira, T.G. 2005. Update on the geographical distribution and habitat of the tapiti (Sylvilagus brasiliensis; Lagomorpha; Leporidae) in the Brazilian Amazon. Mammalia, 69: 245-250.

Swihart, R.K. 1986. Home range - body mass allometry in rabbits and hares (Leporidae). Acta Theriologica, 31: 139-148.

Thrash, I.; Theron, G.K. \& Bothma, J.P. 1995. Dry season herbivore densities around drinking troughs in the Kruger National Park. Journal of Arid Environment, 29: 213-219.

Valeix, M.; Chamaillé-Jammes, S. \& Fritz, H. 2007. Interference competition and temporal niche shifts - elephants and herbivore communities at waterholes. Oecologia, 153: 739-748.

Worton, B.J. 1989. Kernel methods for estimating the utilization distribution in home-range. Ecology, 70: 164-168.

Wright, S.J.; Zeballos, H.; Domínguez, I.; Gallardo, M.M.; Moreno, M.C. \& Ibáñnez, R. 2000. Poachers alter mammal abundance; seed dispersal; and seed predation in a Neotropical Forest. Conservation Biology, 14: 227-239.

Zar, J.H. 2010. Biostatistical Analysis; 5. ed. New Jersey, Prentice Hall/ Pearson. 